\title{
Research on Government Supervision System of Housing Safety Appraisal Institution
}

\author{
Yihua Mao, a , Haiwei Huang ${ }^{1, b^{*}}$ and Yabing Liu ${ }^{1, c}$ \\ ${ }^{1}$ Zhejiang University, College of Civil Engineering and Architecture, Hangzhou, Zhejiang, China \\ azjumyh@163.com, ${ }^{b} z j u \_h h w @ 163 . c o m,{ }^{c}$ liuyabing@zju.edu.cn
}

Keywords: Housing safety appraisal institution; Government supervision; Organization system; Supervision system; Long-term operation mechanism

\begin{abstract}
In this paper, a complete government supervision system of housing safety appraisal institution is established based on the existing problems in the management of housing safety appraisal institution which come from field investigation and interview, the relevant literature research and actual supervision. The establishment of institutionalized regulatory system can provide the government departments with reference on management, so as to regulate the orderly development of housing safety appraisal industry.
\end{abstract}

\section{Introduction}

With the diversification of housing property rights, especially the privatization of housing property rights and the gradual increase in people's legal awareness, housing safety appraisal and management in the aspects of content and methods have made great development. The relevant legal system is also gradually established and plays a more important role.

At present, the housing safety appraisal and the management work in various places are still in the stage of development and exploration. There is not yet a widely recognized path and mode of development. After the liberalization of the market, the vicious competition at a low price intensifies. The strength of appraisal institution, personnel quality and equipment are uneven, so it's difficult to guarantee the quality of appraisal. Besides, the lack of corresponding laws, regulations, standards and norms hinders the sustainable development of housing safety appraisal and management. Therefore, there is an urgent need to establish a government supervision system for housing safety appraisal institution and take the path of market-oriented and informatization development, so as to promote the continuous and sustainable development of housing safety appraisal and management work.

\section{Literature References}

For research on the government supervision of foreign housing safety appraisal institutions, Thomas found that the United States established a multi-level housing management system and the relevant appraisal standards. the law also provides that: the safety status of buildings and their appendages should be appraised regularly by specialized departments or engineers. And the appraisal report is issued after appraisal, which has the force of law [1]. Connolly found that the Building Surveyors industry originated in the United Kingdom and provided services such as safety appraisal and asset assessment of properties and their facilities. In addition, the UK also has a more complete legal system and management department [2]. T. Xu studied the supervision situation in Germany. The German government has no qualification requirements for appraisal institutions, but it has strict requirements on the qualifications of practitioners. Only the quality supervision engineers qualified by the government are eligible to set up an appraisal institution [3].

Since 2008, many domestic scholars began to study the management functions of the government under the supervision of the housing safety appraisal institutions. Based on the analysis of four stages of the housing safety appraisal in our country, X.F. Li thought that the housing appraisal institution should take the road of market-oriented and professional development, and put forward the development principles of conditional marketization, professionalization of appraisers 
and government guidance [4]. According to the practical experience of Guangzhou, W.Z. He analyzed the supervision functions of management department from the aspects of management mode of appraisal institutions and appraisers, the management of appraisal reports and the formulation of technical standards [5]. K.H. Ji believed that the qualification of institutions and practitioners should be divided, and the scope of accreditation should be divided according to the qualification levels [6]. Z.C. Liu proposed that the appraisal institution should implement the legal person responsibility system, step up business promotion efforts and strengthen business training [7]. X.W. Zeng identified the work instructions of appraisal institution and put forward the quality requirements and management regulations based on the total quality management theory [8]. J. Chen conducted an analysis on the program-based management of the project files, including the elements of standardization, the steps of program-based management and the advantages of standardization management [9]. C.S. Zhang used the concept of big data to look forward to the future development trend of housing safety appraisal. He hoped to build an urban housing safety database so the regulators can use the online platform to implement efficient online management [10].

\section{Establish the Government Supervision System}

To establish a supervision system of housing safety appraisal institution, it is necessary to determine the organizational structure and division of functions of the management department from two aspects: the organization system and the supervisory system of the management department. Also, we propose the construction of long-term mechanism to safeguard the operation of the supervision system.

The Organization System of Management Department. The management departments of housing safety appraisal institution consist of municipal-level management department, district and county-level management department and relevant qualification management department. The organizational structure between each management department and the appraisal institution is shown in Fig. 1.

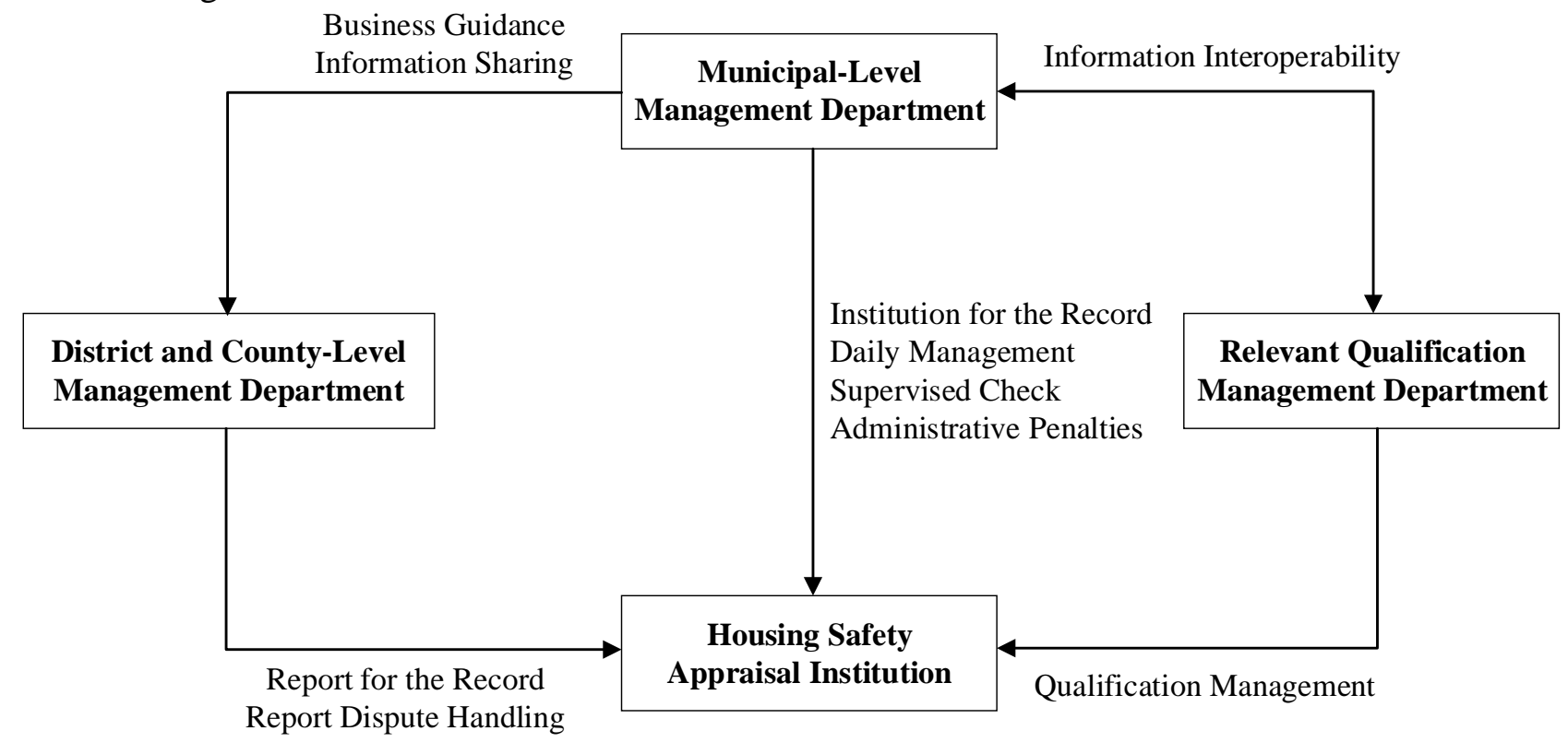

Figure 1. The structure of organization system

Judging from the current management situation, the above-mentioned organizational structure of the housing safety appraisal management department can basically complete the tasks of management work. In addition, the municipal-level management department should make a unified division of district and county-level management department, in order to facilitate the smooth implementation of management work.

According to practical experience, different levels of management department have different 
responsibilities. As follows: the municipal-level management department is mainly responsible for the overall coordination and implementation of housing safety appraisal management work. The district and county-level management department is in the basic position of the housing safety management system and has the responsibility to implement and coordinate the work. The main functions of the relevant qualification management department are to issue the corresponding qualifications to the appraisal institution and promptly punish the bad behavior of the institution in accordance with the regulations on management.

The supervision system of management department. The supervision system includes the daily regulatory system, the record management system, the information management system and the credit information management system. The daily supervision system runs through the whole process of supervision and the contents of other three supervision systems are also an important part of the daily supervision system. In addition, we put forward some new development directions and requirements from the aspects of strengthening daily supervision, enriching supervision means, examining the results of disposal measures, giving play to the role of expert committees, setting up trade associations, strengthening the training of appraisers, standardization of appraisal reports and contracts, guiding the price. The record management system, the information management system and the credit information management system sort out the most important three parts of management contents. Then we build the corresponding system framework and make recommendations and requirements for the optimization and development of the management system. The design of specific supervision system is shown in Fig. 2.

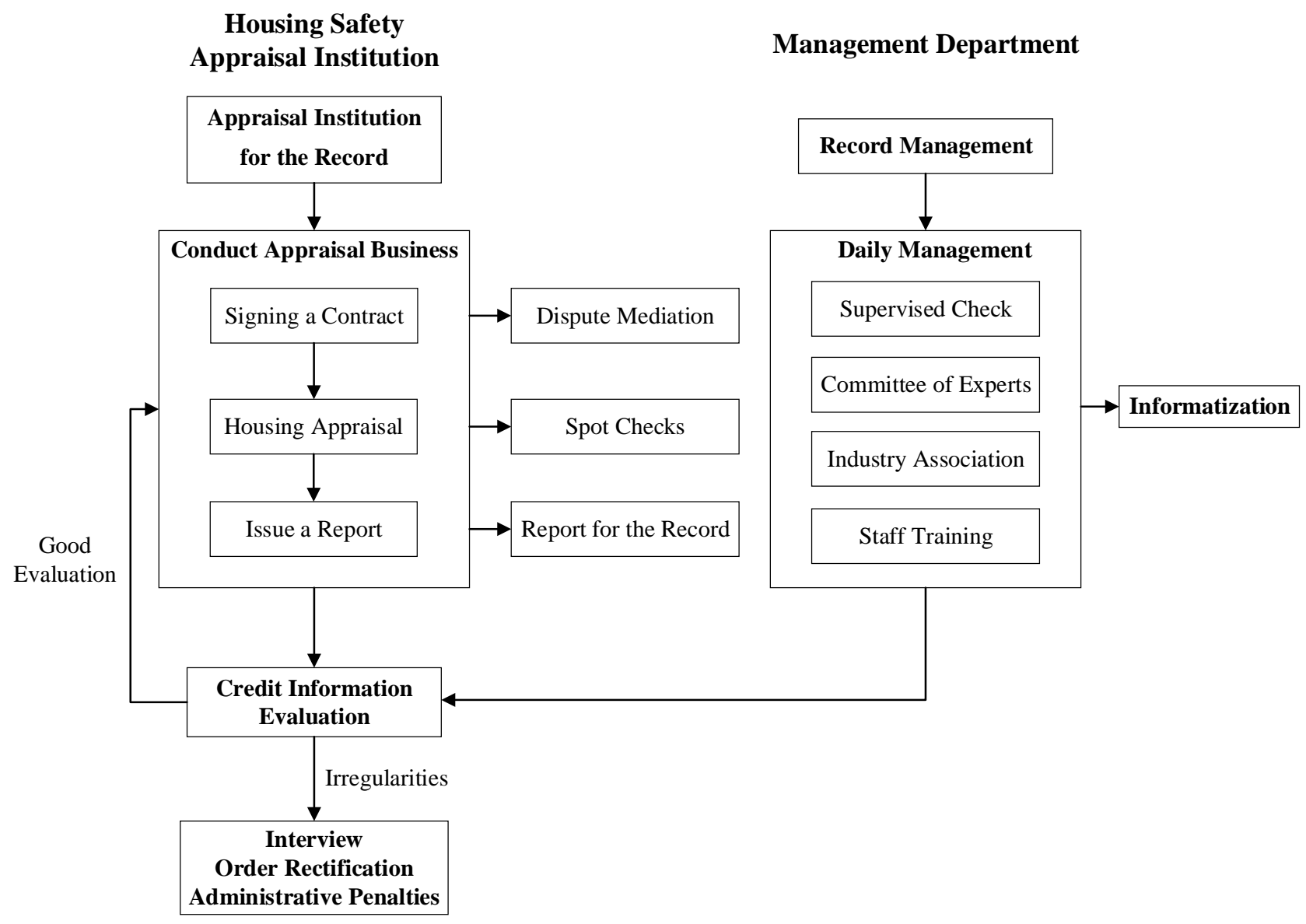

Figure 2. The structure of supervision system

The four systems complement each other, providing the theoretical support and technical guidance for the supervision of appraisal institutions. It is the basis for achieving the orderly and healthy development of the housing safety appraisal industry, as well as the guarantee for the modern market supervision mode of network management, honesty and standardization. 
The long-term mechanism of supervision system. The long-term mechanism of the supervision system mainly includes the following four aspects. First, strengthen organization and leadership: improve the organization and supervision system, clearly manage the main body of the departments, set up a working mechanism that all levels of departments work together, form a work pattern of departmental cooperation and orderly promote the development of housing safety appraisal industry. Second, improve the policies and regulations: research and formulate policies and measures to promote the development of housing safety appraisal industry, and gradually improve the legal system to create a good environment for the rule of law. Third, the implementation of the target assessment: according to the key work objectives of housing safety appraisal industry, management departments at all levels should be based on the actual work to develop the corresponding plan and make the work performance into annual performance assessment. Besides, a clear short-term and long-term development goals, the main tasks and safeguards are also important. Fourth, expand publicity and guidance: to carry out a wide range of publicity and guidance, establish a publicity mechanism combining the government, the media, the appraisal institution and the public, regularly organize publicity activities, and carry out a variety of housing safety appraisal knowledge popularization. So as to raise public awareness of the importance of housing safety appraisal and create a good market atmosphere for the development of appraisal industry.

\section{Conclusions}

Based on the actual problems existing in the process of government supervision and many related literatures both at home and abroad, this paper establishes a set of government supervision system of housing safety appraisal institution including the organization system and the supervisory system and the long-term mechanism. This effective housing safety appraisal industry supervision system can help government departments to regulate the market behavior of housing safety appraisal institutions and promote the orderly development of the housing quality and safety appraisal and the management work. At the same time, provide references for the follow-up related research, but also provide policy-making references for the management departments around the country based on their actual situation.

\section{References}

[1] G. Thomas Kingsley and Raymond J. Struyk: The New Palgrave Dictionary of Economics, Vol. 9 (2008) No.1, p.39.

[2] Connolly M and Knox C: Public Administration, Vol. 69 (2010) No.3, p.303.

[3] T. Xu: Researches on the Development of the Housing Security Detection and Identification (MS., Tianjin University, China 2015), p.23. (In Chinese)

[4] X.F. Li: The 70th Engineering Science, Technology Forum and Symposium of Chinese Academy of Engineering (Beijing, China, April 19, 2008). Vol. 1, p.48. (In Chinese)

[5] W.Z. He: Housing Science, Vol. 36 (2011) No.1, p.31. (In Chinese)

[6] K.H. Ji: Urban Construction Theory Research, Vol. 29 (2012) No.2, p.17. (In Chinese)

[7] Z.C. Liu: Housing Safety Appraisal Cases (China Architecture \& Building Press, China 2014), p.83. (In Chinese)

[8] X.W. Zeng and C.M. Qi: National Housing Safety Management and Appraisal Forum (Shanghai, China, April 27, 2011). Vol. 1, p.79. (In Chinese)

[9] J. Chen: Art and Literature for the Masses, Vol. 11 (2010) No.1, p.186. (In Chinese)

[10]C.S. Zhang: Urban Construction Theory Research, Vol. 60 (2016) No.9, p.30. (In Chinese) 